\title{
Preparation of Future Preschool Education Specialists for the Use of Modern Educational Technologies
}

\author{
Sabina Ivanchuk ${ }^{1}$, Anna Voznik $^{1}$, Olga Dronova ${ }^{1}$, Nina Girenko ${ }^{1}$, Dilyana Arsova ${ }^{2}$ \\ ${ }^{1}$ Donbas State Pedagogical University, Slovyansk, Ukraine. \\ ${ }^{2}$ St.Cyril and St.Methodius University of Veliko Tarnovo, Bulguria. \\ Correspondence: Mariana Mateeva Petrova, St.Cyril and St.Methodius University of Veliko Tarnovo, Bulgaria.
}

Received: June 6, 2020

doi:10.5430/ijhe.v9n5p28
Accepted: June 25, 2020

Online Published: June 26, 2020

\begin{abstract}
The article considers the professional training of future specialists in preschool education. The focus is on the use of modern educational technologies by future preschool education specialists. Basic concepts such as: technologies, educational technologies, innovative technologies are revealed. The modern directions of professional education of future employees of preschool education are analyzed. The necessity of modern educational technologies for future employees of preschool education is singled out and substantiated. It is proved that the preparation for the use of modern educational technologies by future specialists of preschool education is aimed at the constant development of various activities aimed at preserving and developing the younger generation.
\end{abstract}

Keywords: educational technologies, innovative technologies, professional education of preschool specialists, technologies

\section{Introduction}

The modern system of preschool education provides for transition to a flexible, dynamic degree system of training. Formation of a network of higher education institutions capable of educational and qualification levels, types, forms and terms of study, sources of funding to meet the interests of the individual, the needs of each region and state.

Ukraine needs teachers in preschool education who can use modern educational technologies on the same level as in Teacher work is achieving goal of education - the formation of a harmoniously developed personality. Modern world society orients Ukrainian society on democratic principles, reorganization of the preschool education system (change in the ratio of family and social preschool education, diversification of its forms, variety of educational programs). It is these conditions that necessitate changes in the system of training preschool education teachers. .

In the pedagogical dictionary, the term "training" is interpreted as a set of special knowledge, skills, personality traits, work experience and norms of behavior that provide the opportunity to work successfully in the chosen profession (Pedagogical Encyclopedia, 1988).

In our opinion, the professional development of the future educator in the process of his training in high school involves not only mastering a certain set of knowledge, skills, but also his personal self-improvement, activation of professional position, education of such qualities as communication, tact, criticism and more. Note that the factor of success of his professional activity is the formation, the integrity of his personality. The level of preparation of the future educator to work in a different age group is determined by the formation of the necessary knowledge, skills and abilities.

Higher education institutions in Ukraine create and implement a set of measures to ensure the effectiveness of professional training of preschool education professionals through their use of modern educational technologies (Diachok et al, 2020; Duginets \& Petrova, 2020; Zagorodnya et al, 2020). This applies primarily to the implementation of the regulatory framework of the preschool education system: the formation of the child's personality, the development of his creative abilities, the acquisition of social experience; ensuring social adaptation and readiness to continue education, etc.

From this point of view, higher education institutions understand that the training of future preschool education specialists is not possible without understanding the important determinants of how members of higher education differ in their focus on change. Employees of educational institutions must use implicit theories and related goals 
have a significant impact on the innovation of all teaching staff. Signs of increased commitment to theories of subjects and focus on goals aimed at avoiding effectiveness should be perceived as dangerous signals if they are present in innovative higher education institutions (Tahani et al, 2018).

To successfully carry out pedagogical activities, the educator acquires knowledge of preschool pedagogy, child psychology, individual psychological characteristics, age physiology, pediatrics and hygiene, the rules of life protection and health of children. At the same time he needs to master the principles that at the general theoretical level modernize the purpose, objectives, principles, content of education and training of children, as well as optimal conditions, forms, methods and means of educational process, games, intellectual and physical work, art, space life of children (Ponimanska, 2006).

Modern educational technologies reflect the general strategy of education development as a single educational space. The purpose of educational technologies is to solve strategic tasks for the education system: forecasting the development of education, design and planning of goals, results, main stages, methods, organizational forms of the educational process.

That is why the problem of training future specialists in preschool education to use modern educational technologies is quite complex. This requires a concerted effort of representatives of different courses and disciplines, which will be able to form a systematic idea of the need to use modern educational technologies by future employees of preschool education.

The purpose of the article is to reveal the role of modern educational technologies in the professional training of future preschool education specialists.

\section{Objectives of the study:}

1 to analyze modern directions of professional education of future employees of preschool education;

2 to single out and substantiate the need for modern educational technologies for future employees of preschool education.

\section{Analysis of the Research and Publications}

In pedagogical science and practice considerable attention is paid to the problem of professional training of future teachers of preschool education, namely: the essence of the competence approach (Bogush, 2012); formation of professional competence of educators in the conditions of introduction of degree preparation (Belenka, 2012); formation of artistic and constructive skills (N. Golota, 2019); monitoring the quality of professional training (E. Karpova); essence of artistic and pedagogical training (G. Pidkurganna); readiness of students for aesthetic education of preschoolers by means of Ukrainian folk decorative art (O. Polishchuk).

It should be noted that the term "pedagogical technologies" has been increasingly used since the early 1980s. There is no single point of view in defining their essence: some understand it as a certain system of guidelines for the use of modern teaching methods and tools (Petrova, Buzko \& Dyachenko, 2018); other purposeful use of techniques, tools, actions to improve the effectiveness of training (Jarmusevica et al, 2020A; Jarmusevica et al, 2020B); third - a holistic process of defining the purpose, justification of the plan and program of actions and teaching methods (Badjanova et al, 2020; Badjanova et al, 2018; Valdmane et al, 2020). Each of these approaches has a right to exist because it covers different aspects of the learning process. Therefore, there are a large number of pedagogical technologies, but we want to single out modern technologies that can be used by future educators in their professional activities.

The concept of "technology" originated in world pedagogy as well as the opposition to the existing concept of "method". The disadvantage of this method is its inflexibility and statistics. The term "technology" ("technology in education") became widespread in the 1940's and was associated with the use of new audiovisual teaching aids. In the 1960's, the concept of "education technology" was considered from the point of view of software training and the use of computer technology in education (Vyshnyakova, 1999).

Speaking of modern technologies, it is worth emphasizing the concept of "innovation", which means updating the learning process, which is based mainly on internal factors. (Ghimire, 2020; Mikhailov, Karasev \& Mikhailov, 2018; Baklanova, Petrova \& Koval, 2020; Bacho et al, 2019; Levashova, 2011). Borrowing this term is associated with the desire to highlight the motivational side of learning, to dissociate from the next "winning techniques", which in a short time should give maximum effect regardless of the characteristics of the class and individual students, their desires, abilities and more.

That is why "modern technologies" should be considered as "innovative technologies". In turn, this definition is 
considered as a purposeful systematic set of techniques, means of organizing educational activities, covering the entire educational process.

Note that the use of traditional educational technologies is not effective over time. The purpose of the state National Program "Education" ("Ukraine of the XXI century") is to bring education in Ukraine to the level of developed countries, which is possible only with the departure from authoritarian pedagogy and the introduction of modern pedagogical technologies. This is the reason for the attention of teachers and methodologists to innovation. (Petrova et al, 2020; Mussapirov et al, 2019; Naama, 2001)

NM Karpenko studied the professional pedagogical training of preschool education specialists in Swedish universities. The researcher notes that today Swedish university education is a multilevel system that prepares bachelors, masters, bachelors and doctors and offers both general academic and professional programs. After the implementation of educational programs of different levels, students can receive general or professional diplomas, as well as different types of degrees, which are determined by the Resolution on Higher Education (Karpenko, 2010).

The study suggests that teacher education in Sweden is innovation-oriented, and therefore contributes to the preparation of future professionals in the field of preschool education for innovative professional activities (Kozak, 2017).

When researching on the use of modern educational technologies, it is worth emphasizing the mobility of future preschool education specialists. After all, it is the mobility of future professionals that allows them to effectively use innovative educational technologies (Serpa et al, 2020).

Based on the analysis of the scientific literature, several approaches to the interpretation of the term "educational (pedagogical) technology" are identified: educational technology as the latest learning tool; educational technology as a pedagogical system; educational technology as a set of actions (system of actions) or activity; educational technology as a project (model) of the educational process; educational technology as a branch of science or pedagogical knowledge or science.

Educational technology - a system of functioning of all components of the pedagogical process, built on a scientific basis, programmed in time and space, which ensures the achievement of the intended results.

Before using educational technologies, a preschool teacher must be familiar with its structure. Educational technology consists of target (purpose of technology), content (content), procedural, the technological process itself, namely the interaction of subjects and objects of technology, their forms, methods, tools), result-analytical (result and its analysis) components.

After analyzing the scientific literature, we came to the conclusion that today future specialists in preschool education are taught to apply in their professional activities the traditional system of knowledge transfer, skills and abilities. Note that modern society does not have time to increase the rate of knowledge and professional competencies. Peculiarities of the application of modern educational technologies are their openness to the future, the ability to predict on the basis of constant reassessment of values, the willingness to take constructive action in new situations, which are based on innovative technologies. Innovative technologies are related to general processes in society, global problems, integration of knowledge and forms of social life. They provide conditions for personal development.One of the main tasks of ensuring the quality of education is to put the education system in a mode of innovative development. This process will be possible through the implantation of modern innovative technologies in practice and ensuring the innovative activities of preschool education.

The analysis of scientific psychological and pedagogical literature, modern research, the system of professional training of future educators of preschool educational institutions revealed the need to correct some of its components through the use of innovative technologies by future specialists in preschool education.

\section{Methods}

The theoretical and methodological basis of the study is a systematic approach to studying the problem of training specialists in future preschool education to use modern educational technologies. The following general scientific methods were used to solve the set tasks:

1) method of analysis and synthesis (in order to reveal the conceptual and categorical apparatus of research and scientific substantiation of training specialists in future preschool education for the use of modern educational technologies);

2) scientific abstraction, induction and deduction (during the generalization of domestic and foreign experience in the use of modern educational technologies by future specialists in preschool education); 
3) abstract-logical (for theoretical generalization of research results and formulation of conclusions);

4) special methods: mathematical and statistical processing of research results - for the analysis of the received data, ranking, scaling, registration, systematization and differentiation, grouping, graphic expression of data.

The use of a set of methods allowed to obtain objective information about the use of modern educational technologies by future specialists in preschool education. The results of the study are presented using diagrams, tables and graphs.

\section{Results Analysis}

The use of educational technologies by future specialists in preschool education is a specific and quite complex process that requires special knowledge, skills and abilities. Therefore, one of the ways to modernize the educational system of Ukraine is the introduction of modern educational technologies in the educational process of ZDO (Table 1).

Table 1. Modern educational technologies

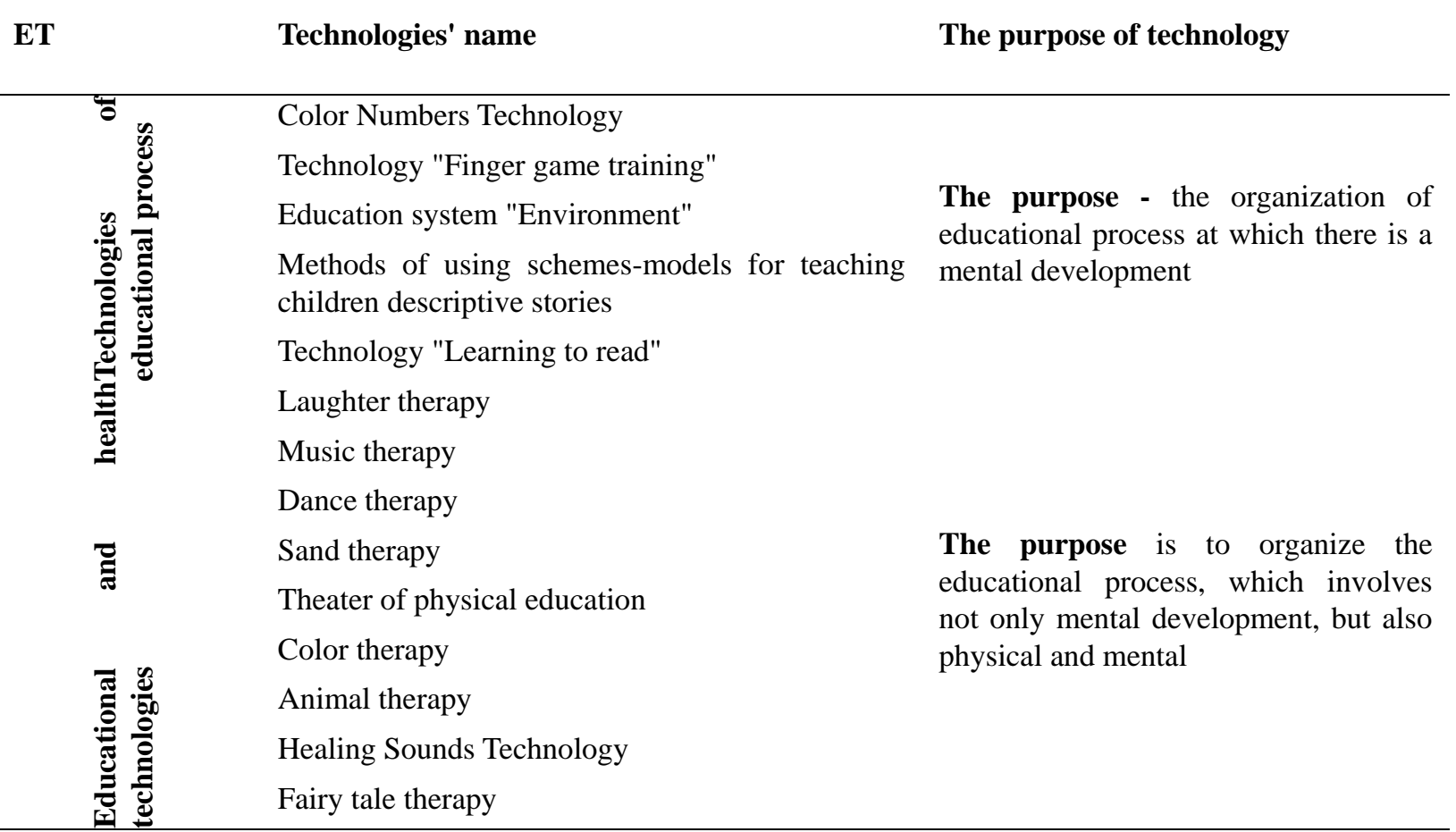

Source: developed by the authors

The use of innovative technologies by future preschool education specialists helps to significantly optimize the educational process in preschool education institutions. Therefore, one of the rules of using modern technologies by future educators is often and the most diverse use of them. After all, innovative technologies are easy to use, give students great pleasure, and most importantly - have an effective comprehensive impact on their development. The diversity of technologies is explained by the fact that they can be used in various organizational forms of work, in everyday life, integrating them into various activities of children.

It is stated that the educational process in a modern preschool educational institution is possible only as a careful reproduction of pre-designed modern educational technology by preschool education specialists, clearly defined tasks in conjunction with adequate technology for their solution, which makes it possible to transform the work of preschool education. there is little orderly set of actions of educators in the purposeful process of work of all pedagogical collective. 


\section{Results and Discussions}

Innovative pedagogical technologies have a humanistic orientation in the education system, due to the coexistence and complex relationships in scientific pedagogy and pedagogical practice of traditional scientific pedagogy. They belong to the system of general scientific and pedagogical knowledge. Arised and developed on the border of general innovation, methodology, theory and history of pedagogy, psychology, sociology and management theory, economics of education. Innovative pedagogical technologies are one of the dominant trends in human development.

Future preschool education professionals must learn to combine differences in statements about the practice of co-learning (a combination of online instruction and face-to-face) when using modern educational technologies. The application of modern educational technologies and their combination in different forms and styles of learning will have a significant impact on the formation of professional competence (Hamonangan et al, 2019).

Considering the different approaches to the concept, we can say that the use of modern educational technologies, future professionals in preschool education, is part of the professional competence of the educator of preschool education (Zhadlenko, 2017) And from yes, is an integrative professional system knowledge, practical skills, significant personal qualities and experience that determine the formation of readiness to perform professional and pedagogical activities. Undoubtedly, the above testifies to the high level of self-organization of future specialists in preschool education.

A comparative analysis of domestic and foreign experience shows that innovative pedagogical technologies are considered not only as a focus on the perception, production and application of the new, but above all as openness. They provide the conditions for the development of the individual, the exercise of his right to individual creative contribution, to personal initiative, to freedom of self-development.

We consider it necessary to highlight the characteristics of modern basic technologies: algorithmic, systematic, efficient, optimal, diagnostic, hierarchical.

Algorithmicity indicates that technologies are characterized by a set or sequence of actions (algorithm of actions), the implementation of which guarantees the realization of goals.

Systematic means the relationship of the main interconnected components of technology, which are the purpose, content, forms, methods, means of interaction of participants in the pedagogical process, as well as the result.

Efficiency is defined as the ratio of the result to the number of resources used.

Optimality involves obtaining the maximum result at low cost, ie with the least amount of resources used.

Diagnostics indicates that the implementation of technology is impossible without a diagnostically defined goal and diagnosis of the achieved result.

Hierarchy means that there are different in importance and use of technology. Some of them are used at the level of the educational institution, others - only during the study of a particular discipline.

It is emphasized that the training of future specialists in preschool education should be a guideline for innovation and respond to the development of knowledge and technology in accordance with the needs of industry and civil society. As a result, we will have future preschool education professionals with the potential to develop technologies. This process will be possible with the beginning of writing by future specialists in preschool education research papers in their fields of study (Rokhayati Rosa\&Mujiarto, 2020).

It is stated that the mastery of innovative technologies by future specialists of preschool education has no narrow professional limits, as it requires constant understanding of the variety of social, psychological, pedagogical and other problems associated with the organization of the educational process of preschool education. And from so, ways of use of modern educational technologies by the future experts of preschool education will differ from each other in the purpose, tasks, principles, etc.

Innovative educational technologies are specific and quite complex, require special knowledge, skills, abilities, especially from future specialists in preschool education. Innovative pedagogical technologies in the education system testify to a qualitatively new stage of interaction and development of scientific and pedagogical and pedagogical creativity and processes of application of its results. The complexity and versatility of pedagogical activity is a factor that opens space for many innovative technologies, the dynamics of production of which is constantly growing.

The use of innovative technologies by preschool teachers is a complex process that requires skillful, flexible, constructive application. 
We highlight that the implementation of innovative pedagogical technologies significantly changes the educational process, which allows to solve problems of developmental, personality-oriented learning, differentiation, humanization, formation individual educational perspective. At the same time, there is an increase in pedagogical skills and professional competence of preschool teachers, the formation of a modern style of thinking with its characteristics (creativity, system, flexibility, dynamism, prospects, objectivity, conceptuality) at the level of the individual.

\section{Conclusions}

The problem of the modern preschool teachers' formation has been reflected in many scientific studies.

According to the results of the study, the following conclusions were made - the priority of the higher education system is the training of a preschool education specialist based on the formation of his worldview, beliefs, creative abilities, professional flexibility.

The growing demand for higher education has been adapted to the unique needs of each person. This has become a driving force in the development of new technologies aimed at providing students with more choice and better control of knowledge. Modern achievements in the development of educational learning technologies make it possible to maintain the individual educational trajectory of future preschool teachers. One of the main obstacles, however, is that educational technology is constantly emerging. Adaptive learning is still developing and is only gaining momentum in higher education. That is why higher education should provide opportunities for future preschool teachers to constantly use modern educational technologies.

The formation and development of the necessary professional pedagogical skills of future preschool teachers occurs during the application of various educational technologies in the educational process, during the internship and extracurricular activities.

The preschool teacher must be able to implement in educational standards new educational technologies. This process requires the effective organization of holistic education in higher education, updating the content of professional training, finding appropriate tools, methods and forms of its implementation. Consequently, modern higher education should focus on the formation of professional and creative personality, teachers of preschool education of innovative type.

It is proved that the preparation for the use of modern educational technologies by future specialists of preschool education is aimed at the constant development of various activities aimed at preserving and developing the younger generation. The main purpose of modern educational technologies - to unite teachers, psychologists, parents and most importantly - the children themselves for their own preservation and development.

The use of innovative technologies by preschool teachers will help improve the quality of the educational process under the following conditions: appropriate moral and psychological climate; constant improvement of material and technical base and didactic support of educational process; multilevel and flexibility in the construction of content, forms, methods and means of teaching, taking into account the specifics of the educational institution, professional needs and individual requests of teachers; advanced nature of training; strengthening the practical orientation of professional education.

The implementation of these conditions will contribute to the growth of pedagogical skills of future preschool teachers.

At the same time, the problem of application of innovative technologies by future specialists of preschool education in different age groups of preschool education institution remains insufficiently developed, which is a prospect of further explorations.

\section{References}

Aronova, R. S.(2016). Formation of professional competence of future specialists of preschool education in pedagogical colleges [in Ukraine].Candidate's thesis (Theory and Methods of Vocational Training). Kyiv.

Bacho, R., Pukala, R., Hlibko, S., Vnukova, N., Pola, P. (2019). Information Management: the Key Driver of the Economic System's Development. Marketing and Management of Innovations, 3, 297-307. http://doi.org/10.21272/mmi.2019.3-23

Badjanova J., Iliško Dz., Ignatjeva Sv., Petrova M., Gorbunovs A. (2020). Evaluation and analysis of personality traits of Latvian and Bulgarian Inhabitants. International Conference on Natural Sciences and Humanities (ICONSH'20), 30-31, March, in Athens, Greece(inprint). 
Badjanova, J., Ilisko, Dz., Petrova, M. (2018). Definition and Dynamics of Gender-Specific Behaviours of Latvian Males and Females.Rural Environment. Education. Personality (REEP). (2018). Proceedings of the International Scientific Conference, 11, 11th-12th May 2018. Jelgava, Latvia, 53-58. https://doi.org/10.22616/REEP.2018.005

Baklanova, O., Petrova, M., Koval, V. (2020). Institutional transmission in economic development, Ikonomicheski Izsledvania (Economic Studies), 29(1), 68-91.

Belenka, G. V. (2012). Theoretical and methodical bases of formation of professional competence of educators of preschool educational institutions in the conditions of degree preparation[in Ukraine].Doctor's thesis (preschool education). Kyiv.

Belenka, G. V. (2006). Preschool teacher: his formation and development [in Ukraine]. Monography, 304.

Bogush, A. M. (2012). Communicative and speech support of professional development of the personality of the future educator of a preschool educational institution in the southern region of Ukraine [in Ukraine]. Science. center of the National Academy of Pedagogical Sciences of Ukraine.P. 80-116.

Chupryakova, A., Zakonnova, L., Petrova, M. (2020). Benchmarking as a determinant of modern mining education. E3S Web of Conferences Volume 174 (2020). V V $^{\text {th }}$ IIMS, Kemerovo, Russian Federation, October 14-16, 2020. https://doi.org/10.1051/e3sconf/202017404053

Diachok, N., Chernukha, N., Tokaruk, L., Udovenko, L., Petrova, M. (2020). Practical-oriented concept as a principle of professional education of the future professionals. International Journal of Higher Education, 9(4), August 2020, 272-282. https://doi.org/10.5430/ijhe.v9n4p272

Dyachenko, Yu., Nenkov, N., Petrova, M., Skarga-Bandurova, I., Soloviov, O. (2018). Approaches to Cognitive Architecture of Autonomous Intelligent Agent. Biologically Inspired Cognitive Architectures, Elsevier, 26, 130-135. https://doi.org/10.1016/j.bica.2018.10.004

Duginets, G., Petrova, M. (2020). The essence of hybrid wars in the XXI century.Professional competencies and educational innovations in the knowledge economy: collectivemonograph / Ed: Lyubomira Popova, Mariana Petrova. Veliko Tarnovo, Bulgaria: Publishing House ACCESS PRESS, 2020. -552 p.ISBN 978-619-91511-0-5, 174-189. http://access-bg.org/ebooks

Golota, N. (2019) Formation of leadership qualities of future teachers of primary school in professional preparation Advances in Social Science, Education and Humanities Research 4th International Conference on Social, Business, and Academic Leadership (ICSBAL 2019) (359). C. 216-220. ISSN 978-94-6252-821-5

Ghimire, R.P. (2020). Scientific Enquiry into the Flat Social Media Innovation based Modelling of Flat Social Entrepreneurship for Economic and Non-Economic Opportunities. Access journal, ACCESS Press, 1(1), 31-38. https://doi.org/10.46656/access.2020.1.1(2)

Hamonangan Tambunan, Marsangkap Silitonga, Uli Basa Sidabutar. (2020).Teaching Technical Teacher Candidates with Various Types of Learning Styles: Online and Face-to-Face Compounds. International Journal of Higher Education, 8(5), 2019. https://doi.org/10.5430/ijhe.v8n5p233

Jarmusevica, V.; Ilisko, D.; Badjanova, J.; Jukss, V.; Petrova, M. (2019A). Educating citizens for integrating the strategy of corporate social responsibility for sustainable regional development: the case study. Proceedings of EDULEARN19 Conference 1st-3rd July 2019, Palma, Mallorca, Spain, 10449-10454, https://library.iated.org/view/JARMUSEVICA2019EDU,ISSN:2340-1117.

https://doi.org/10.21125/edulearn.2019.2633

Jarmusevica, V.; Ilisko, D.; Badjanova, J.; Jukss, V.; Petrova, M. (2019B). Educating citizens for implementing the strategy of corporate social responsibility for sustainable regional development: the case study. Proceedings of EDULEARN19 Conference 1st-3rd July 2019, Palma, Mallorca, Spain, ISBN 978-84-09-12031-4, 10449-10454.

Karpenko, N. M. (2010). Professional and pedagogical training of preschool education specialists in Swedish universities[in Ukraine].Candidate's thesis (Theory and Methods of Vocational Training).Kyiv.

Kozak, L. V. (2017). Preparing forward specialists for preschool education: european experience[in Ukraine].Continuing professional education: theory and practice (series: pedagogical sciences).N. 43-4 (52-53). https://doi.org/10.28925/1609-8595.2017(3-4)136142

Levashova, L. (2011). Marketing wewnętrzny w kontekście motywowania pracowników, w: Świerszcz K. i Nowacki 
W., Ksztaltowanie lojalności klientów w teorii $i$ w praktyce. Warszawa: Wydawnictwo Warszawska Wyższa Szkoła Ekonomiczna.

Mikhailov, V., Karasev, V., Mikhailov, G. (2018). The Study of the Main Indicators of the Local Environmental and Economic System "Industrial Enterprise-Environment". E3S Web Conf.41, 2018. III ${ }^{\text {rd }}$ International Innovative Mining Symposium.https://doi.org/10.1051/e3sconf/20184102015

Mushkudiani, Z., Gechbaia, B., Gigauri, I., Gulua, E. (2020). Global, economic and technological trends in human resource management development. Access journal, ACCESS Press, 1(1), 53-60. https://doi.org/10.46656/access.2020.1.1(4)

Mussapirov, K., Djalkibaev, J., Kurenkeyeva, G.,Kadirbergenova,A., Petrova, M., Zhakypbek, L.(2019). Business scaling through outsourcing and networking: selected case studieS.Entrepreneurship and Sustainability Issues, 7(2), 1480-1495. https://doi.org/10.9770/jesi.2019.7.2(48)

Naama, K. (2001). International Movement of Foreign Direct Investments. Economic Thought journal, Bulgarian Academy of Sciences - Economic Research Institute, 5, 81-92.

Pedagogical Encyclopedia (1988). Ch. Editor Kairova A.I. - Moscow., Sov. Encyclopedia, 1988. T. 3. 880 p.

Petrova M., Buzko I, Dyachenko Yu. (2018). Cognitive, Intelligence Technologies and Economical Foundations of Teaching of International Economical Relations and Tourism. 17th International Scientific Conference ERDev, 23.-25.05.2018. Jelgava, latvia, 1102-1106. https://doi.org/10.22616/ERDev2018.17.N170

Petrova, M., Koval, V., Tepavicharova, M., Zerkal,A., Radchenko, A., Bondarchuk, N. (2020). The interaction between the human resources motivation and the commitment to the organizations. Journal of Security and Sustainability Issues, 9(3). http://doi.org/10.9770/jssi.2020.9.3(15)

Ponimanska, T. I. (2006). Preschool pedagogy: a textbook for students of higher educational institutions [in Ukraine].Kyiv. 456 p.

Rokhayati Rosa, A.T., Mujiarto Mujiarto. (2020). Teacher Development Potential (Creativity and Innovation) Education Management in Engineering Training, Coaching and Writing Works through Scientific Knowledge Intensive Knowledge Based on Web Research in the Industrial Revolution and Societ. International Journal of Higher Education, 9(4). https://doi.org/10.5430/ijhe.v9n4p161

Sandro Serpa (2020).Mobility in the Internationalisation of Higher Education Institutions. International Journal of Higher Education, 9(4), 2020. https://doi.org/10.5430/ijhe.v9n4p46

Tahani Z. Aldahdouh, Petri Nokelainen, Vesa Korhonen. (2018). Innovativeness of Staff in Higher Education - Do Implicit Theories and Goal Orientations Matter? International Journal of Higher Education, 7(2). https://doi.org/10.5430/ijhe.v7n2p43

Valdmane, L., Zarina, S., Iliško, D., Badjanova, J., Petrova, M. (2020). Empowering of Digital and media literacy of primary school teachers in Latvia. EDULEARN20,12th annual International Conference on Education and New Learning Technologies, 6th - 7th of July, 2020 (inprint)

Vishnyakova, S. M. (1996). Professional education: a dictionary. Key concepts, terms, current vocabulary[in Russian]. 538 p. Moscow.

Zagorodnya, A., Dichek, N., Chobitko, N., Voznyk, M., Honchar, L., Petrova, M. (2020). Professional training of the economic sector specialists at higher education institutions of the Republic of Poland and Ukraine: criteria of comparison. International Journal of Higher Education, 9(3), June 2020, 139-144. https://doi.org/10.5430/ijhe.v9n3p139

Zhadlenko, I. O. (2017). Formation of professional and ethical competence of future educators of preschool educational institutions in the process of professional training[in Ukraine].Candidate's thesis (Theory and Methods of Vocational Training). Zaporozhye. 